\title{
Foreign Direct Investment and Growth in ASEAN-4 Nations
}

\author{
Yasmine Merican \\ Universiti Putra Malaysia \\ Serdang, Selangor, Malaysia \\ Tel: 019-3879-109Ｅ-mail: yasmine96@gmail.com
}

\begin{abstract}
The study tested the impact of FDI and Gross Domestic Investment on growth in Malaysia, Thailand, Indonesia, and the Philippines- significant FDI recipients within the developing world in the last three decades. The study's time-series analysis employing the Autoregressive Distributive Lag (ARDL) technique suggests that the FDI is better than Domestic Investment for growth in Malaysia, Indonesia but not for Thailand and the Philippines where the reverse is true.
\end{abstract}

Keywords: Economic growth, Foreign direct investment, Gross domestic investment, Neo-liberal theory, Dependency theory, Globalization

\section{Background}

Amongst developing world nations, the ASEAN-4 nations-Malaysia, Thailand, Indonesia, and the Philippines- have had a significant share of FDI inflows in the last three decades which have been accompanied by high growth. There appears to be a relationship between economic growth and FDI inflows in all the four ASEAN nations. Decreases in FDI are normally followed suit by decreases in growth and vice-versa as illustrated by Table 1 and Figures 1a through 1d. Thus, growth of the ASEAN-4 nations appears dependent upon FDI via multinationals and this dependence is thought to be especially risky against the backdrop of China's current lead as an FDI magnet coupled with India's potential as a second magnet in the near future which could siphon FDI away from the ASEAN-4 further.

Against an uncertain landscape and the rhetoric of the dependency literature that FDI is not as good as Gross Domestic Investment in promoting growth, the main purpose of this study is to test whether Gross Domestic Investment is indeed better than the neo-liberal FDI in promoting growth as postulated by dependency theorists, critiques and detractors of neo-liberal theory as well as of the larger globalization process characterized by the liberalization of trade and investment.

Extending the dependency argument further, it is postulated that growth driven by foreign entities is not as sustainable as growth generated by domestic factors of production since such growth depends on the robustness of foreign economies. In other words, growth based on domestic production factors is more sustainable since domestic governments are able to wield more control over them as opposed to foreign ones. It is also unclear that the ASEAN-4 economies deemed FDI-driven growth would be able to sustain their growth once this capital runs dry. In short, it is unclear whether ASEAN-4 economies are able to generate their own technology independent of the technology associated with FDI to propel growth.

\section{Theoretical literature}

The trend of a falling FDI which accompanies falling growth seems to lend some support to the theoretical perspective of development by dependency theorists, in particular to that of Santos' Structuralist Model of Dependence which points out that the growth in the periphery is very much subjected to the growth in the core (Gosh, 2001, Crane and Amawi, 1991).

Other dependency theorists such as Dixon and Boswell (1996), have postulated the concept of investment dependence based on the extent to which a country's economy is penetrated and controlled by FDI, which is referred to as penetration that is negatively related to growth rates in the long run. Dependency theorists are far more concerned with FDI than with portfolio investment in their measurement of investment dependence. Theorists and researchers sympathetic to dependency theory view investment dependence as a structural feature of a national economy which gives some degrees of economic and political power to those groups at the core. However, theorists and researchers working in the framework of neoclassical economy and neo-liberalism view investment dependence as a mere flow of resources into a country and that the growth rates of the ASEAN-4 nations make them ideal poster children for the free-flow of trade and finance. 
Of equal importance is the view by dependency theorists that the level of foreign investment to be not as "good" as domestic investment in generating economic growth based on "differential productivity." "Differential productivity is the expected result of several underlying mechanisms of "disarticulation" in the forms of tax avoidance, less development of local entrepreneurship, inappropriate technology, less profit reinvestment, and less linkage to domestic business" (Firebaugh, 1992, p.109, Dixon and Boswell, 1996, p. 545). Hence, while dependency theorists do not dispute that FDI in terms of inflows brings about returns, its returns are expected to be lesser than domestic investment.

\section{Empirical Literature}

The first literature surveyed is on the cross-national evidence of the effects of foreign investment and aid on economic growth by Bornschier, Chase-Dunn, and Rubinson (1978). The study finds that economic growth tends to be positively related with FDI flows but tends to be negative with FDI stocks and is independent of geographical region. For Asia, FDI stocks show a significant negative effect on growth but flows only managed a small positive effect (Bornschier, 1980).

Jansen (1995) tests the impact of FDI on growth in Thailand after an upsurge of FDI is found to be of a different nature from the past inflows. The experience of Thailand shows that FDI helps to restore private investment and growth and that export-oriented FDI contributes sharply to an increase in export earnings. On the other hand, FDI also leads to an even sharper increase in import demand, so that the current account deteriorates and the external debt burden grows rather than declines. Although Jansen does not attribute FDI to cause external debt, it sets the motion an adjustment process that does lead to increased external borrowing. In short, the pre-1995 FDI inflow is both export oriented and import intensive.

Dixon and Boswell (1996) study on the impact of both FDI and Domestic Investment Flows on growth supports dependency theory that domestic investment flows are better than FDI in generating growth. The results are based on a panel-study for developing nations which essentially look at differential productivity of FDI and domestic investments.

Sun (1998) investigates the macroeconomic impact of FDI on China from 1979 through 1996. FDI has a significant role in promoting the economic growth of China through contributing to domestic capital formation, increasing exports and creating new employment. However, gross domestic investment is more robust than FDI in generating growth in the Eastern and Western regions of China.

Hsiao and Shen (2003) study is based on the Harrod-Domar's model. This model assumes that FDI raises the productivity of capital through improved competition, positive technological externalities, and accelerated spillover effects. Hsiao and Shen (2003) find that FDI increases GDP and the increase in GDP in turn attracts FDI.

The next literature surveyed is by Mencinger (2003) who poses the question if FDI in developing transitional economies enhance the economic growth of selected Eastern European countries during the post-transition period, and if not, its reasons. Mercinger's correlation coefficients between growth and corresponding FDI are negative in seven out of the eight countries and remain positive for Lithuania. Even pooled data result is a negative correlation coefficient. Mercinger's annual cross-sectional regression between growth and FDI obtained a similar negative result. A similar negative result is obtained by cross-section data for each year and hence, one can conclude that there is a negative correlation between growth and FDI in six out of the eight years with 1997 having a positive sign and 1998, registering insignificant results (Mencinger, 2003).

The final literature surveyed on growth is by Baliamoune-Lutz (2004). Baliamoune-Lutz regresses FDI against growth and exports using time-series data. The study's null hypotheses are as follows: FDI drives growth; Export drives growth. The findings of the study show there is a strong negative correlation between the export ratio and economic growth in the post-1993 years which is the liberalized FDI era for Morocco. The two null-hypotheses that Baliamoune-Lutz accepted are: Growth does not cause FDI; Growth does not cause exports. In addition, FDI and exports have bi-directional causality, apart from having a positive impact from exports to economic growth. Growth is impacted by FDI both directly and indirectly.

\section{Empirical Model}

Hence to test the postulation of the neo-liberal and dependency theories on growth in the ASEAN-4 nations, the following model is proposed [Sahoo and Mathiyazhagan (2003), Sun (1998), Borenzstein, Gregorio, Lee (1998)]:

$$
Y_{t}=\beta_{0}+\beta_{1} D O M_{t}+\beta_{2} F D I_{t}+\beta_{3} E X P T_{t}+\beta_{4} H C_{t}+\varepsilon_{t}
$$

$\begin{array}{lll}Y_{t} & = & \text { Real Gross Domestic Product Per Capita in (US) (1995) Dollars } \\ D O M_{t} & = & \text { Nominal Gross Domestic Investment in terms of \% nominal GDP } \\ F D I_{t} & = & \text { Nominal FDI inflows in terms of \% nominal GDP } \\ E X P T_{t} & = & \text { Nominal Export of Goods and Services as of \% nominal GDP } \\ H C_{t} & = & \text { Adult Illiteracy rate (\%) }\end{array}$


Based on Neo-Liberalism theory, we expect:

$$
\beta_{1}, \beta_{2}, \beta_{3}>0 \quad \beta_{4}<0
$$

Based on dependency theory, we expect:

$$
\beta_{1}>\beta_{2}
$$

The main aim of this model is to verify the postulation of the dependency school that in terms of level of investment impact on growth, FDI is not as good as Gross Domestic Investment. Furthermore, the model will also test if FDI and exports are correlated with growth in the ASEAN-4 nations. Thirdly, the model will also verify the postulation of the dependency school that the neo-liberal FDI increases export dependency in the economy. Fourthly, the model will test if Human Capital Stock enhances growth in the ASEAN-4 nations.

\section{Variables and Data}

Growth, as the dependent variable, is measured by Gross Domestic Product Per Capita in constant 1995 prices using US dollars. The GDP Per Capita data are from the World Bank Development Indicators 2003 CD-ROM.

Collectively, ASEAN nations have been among the most important destinations for FDI in the last two decades (Abdul Rashid and Usmani, 2000). Foreign direct investment is often thought to contribute to growth through technological progress (Borenzstein (1998), Choe (2003), Li and Liu (2004) and managerial skill (Abdul Rashid and Usmani, 2000). Both the neo-liberal and dependency theories agree that FDI inflows tend to impact growth positively. Hence, the null hypothesis that FDI drives growth is tested. The FDI variable is nominal FDI inflows in terms of \% nominal GDP. The FDI flows' data are from UNCTAD's online database. Because of data limitations, the level of FDI penetration which requires the use of stock data is not tested.

Most capital dependency research would support the view that an investment of foreign capital will ordinarily return some productivity improvement but at a lower level than would accrue from a comparable level of domestic investment (Dixon and Boswell, 1996). Hence, the null hypothesis that gross domestic investment brings a greater yield to growth levels than would FDI is also tested in this study. Gross domestic investment will be measured in terms of \% GDP in current prices and sourced from the World Bank Development Indicators 2003 CD-ROM. From the point of view of dependency research, both the FDI and Gross Domestic Investment measurements reflect the level of investment in the ASEAN-4.

Dependency theorists postulate that foreign investment from the advanced capitalist states promotes export and import dependent forms of development (Jaffee, 1986). Samir Amin (1976) elaborates that the general condition of "extraversion"-an excessively outward-looking economic structure finds its source not only in the evolution of colonial trade patterns, but also in the investment of foreign capital into export activities. Amin further elaborates that while there is explicit recognition that capital will be directed toward both the primary product and or manufacturing sectors, which the latter is more relevant to the ASEAN-4 case, the net effect will be a further dependence on external markets.

In opposition to the dependency thesis on the sources of trade dependence, a long tradition in the neo-classical economics focuses on the "natural" limits and factor endowments that lead nations to depend on external markets. According to this perspective, under a certain set of conditions international trade is not only rational but optimally beneficial strategy for meeting economic needs (Jaffee, 1986).

There are several postulations on the precise economic and social consequences of trade dependence. Some argue that a dependence on external trade hampers economic growth due to dramatic fluctuations in world market prices and the inability to make long-range economic plans, given the vagaries of an uncontrolled external market [Prebisch (1959) in Jaffee (1986)]. Others highlight the enclave nature of trade dependent economies and the subsequent lack of balanced and sectorally articulated economic growth [Amin, (1976) and Cardoso and Faleto (1979) in Jaffee (1986)]. Some economists advocate export-oriented strategies as the best means for overcoming underdevelopment and stimulating growth [Krueger (1978) in Jaffee (1986)]. Kohpaiboon (2003) best captures the scenario for the ASEAN-4 nations by stating that FDI better affects growth under an export-promoting (EP) regime than an import-substitution (IS) one because FDI as well as Gross Domestic Investment under an IS regime mostly takes place in sectors characterized by high capital intensity in production where the host country does not have comparative advantage. All the ASEAN-4 nations now emphasize an EP regime over an IS one. To demonstrate export dependence, this study will measure export in terms of the total value of goods and services expressed \% GDP in nominal terms sourced from World Development Indicators CD-Rom 2003.

Human capital will be the rate of adult illiteracy sourced from the World Bank Development Indicators 2003. It is intended to measure the basic educational level of the stock of the population. Human capital stock enhances growth (Sun, 1998). The model will be estimated in the log form. 


\section{Bounds Test Approach}

Based on Pesaran et. al. 2001 modeling approach; the maintained assumption that the time series properties of the variables included in Equation (1) can be well be approximated by a log-linear VAR $(p)$ model is as follows:

$$
z_{t}=\mu+\sum_{i=1}^{p} \beta_{i} z_{t-i}+\varepsilon_{t}
$$

Where $z_{t}$ is the vector of both $x_{t}$ and $y_{t}$ where $y_{t}$, the dependent variable, is defined as $\mathrm{E}$, and $x_{t}=$ [ $\left.D O M_{t} F D I_{t}, E X P T_{t}, H C_{t}\right]$ ', is the vector matrix which represents a set of explanatory variables. $\mu=\left[\mu_{y}, \mu_{x}\right]^{\prime}, \mathrm{t}$ is a time trend variable, $b_{i}$ is a matrix of VAR parameters for lag $i$. According to Pesaran et. al. (2001), $y_{t}$ must be $\mathrm{I}(1)$ variable, but the regressor $x_{t}$ can be either $\mathrm{I}(0)$ or $\mathrm{I}(1)$. Developing the model further:

$$
\Delta z_{t}=\mu+\alpha t+\lambda z_{t-1}+\sum_{i=1}^{p-1} \gamma \Delta y_{t-1}+\sum_{i=0}^{p=1} \varphi_{i} \Delta x_{t-1}+\varepsilon_{t}
$$

where $\Delta$ is the first difference operator. Partitioning the long-run multiplier matrix 1:

$$
\lambda\left[\begin{array}{l}
\lambda_{y y} \lambda_{y x} \\
\lambda_{x y} \lambda_{x x}
\end{array}\right]
$$

The diagonal elements of the matrix are unrestricted, and hence the selected series can be either $\mathrm{I}(0)$ or $\mathrm{I}(1)$. If $\lambda_{y y}=0$, then $\mathrm{y}$ is I(1). In contrast, if $\lambda_{y y}<0$, then $\mathrm{y}$ is $\mathrm{I}(0)$.

The VECM procedure described above is important in the testing at most one cointegrating vector between dependent variable $y_{t}$ and a set of regressors $x_{t}$. The study's preferred model adhered to the assumptions of Pesaran et. al. (2001) in Case III that is unrestricted intercepts and no trends. After imposing the restrictions $\lambda_{x y}=0, \mu \neq 0$, and $\alpha=0$, the growth level specification in terms of the unrestricted error-correction model (UECM):

$$
\begin{aligned}
& \Delta \ln E_{t}=\beta_{0}+\beta_{1} \ln E_{t-1}+B_{2} \ln D O M_{t-1}+\beta_{3 t-1} F D I_{t-1}+\beta_{4} E X P T_{t-1} \\
& +\beta_{5} H C_{t-1}+\beta_{6} \sum_{i=1}^{p} \Delta \ln E_{t-1}+\beta_{7} \sum_{i=0}^{q} \Delta \ln D O M_{t-1}+\beta_{8} \sum_{i=0}^{r} F D I \\
& +\beta_{9} \sum_{i=0}^{s} E X P T_{t-1}+\beta_{10} \sum_{i=0}^{v} H C_{t-1}+u_{t} . .(4)
\end{aligned}
$$

where $\Delta$ is the first-difference operator, $u_{t}$ is a white noise disturbance term. Equation (4) can also be viewed as an ARDL order of (p, q, r, s, v). The structural lags are determined by using minimum Aikake's information criteria (AIC). In this case, the long-run elasticity is derived by dividing each of the one lagged explanatory variable by the coefficient of the one lagged dependent variable.

After obtaining Equation (4), the Wald test (F-statistic) was computed to discern the long-run relationship between the concerned variables. The Wald test can be conducted by imposing restrictions on the estimated long-run coefficients of, DOM, FDI, EXPT, HC, and GDP. The null and alternative hypotheses are as follows:

Ho: $\beta_{1}=\beta_{2}=\beta_{3}=\beta_{4}=\beta_{5}=0 \quad$ (no long-run relationship)

Ha: $\beta_{1} \neq \beta_{2} \neq \beta_{3} \neq \beta_{4} \neq \beta_{5} \neq 0$ (a long-run relationship exists)

The computed F-statisic value will be compared with the critical values tabulated in Table CI (III) of Pesaran et al. (2001). If the computed F-statistic is smaller than the lower bound value, then the null hypothesis is not rejected, then there is no long-run relationship between growth and its determinants. Alternatively, if the computed F-statistic is greater than the upper bound value, then growth and its determinants share a long-run level relationship. However, if the computed F-statistic falls within these bounds, the inference would be an inconclusive one.

\section{Bounds Test Results and Discussion}

The Bounds Test was used on all models to investigate the presence of a long run relationship among the variables specified for each country. In Table 2, the results of Pesaran et. al (2001) bounds test obviously demonstrates that the 
null hypothesis $\mathrm{c}(1)=\mathrm{c}(2)=\mathrm{c}(3)=\mathrm{c}(4)=\mathrm{c}(5)=0$ against its alternative, $\mathrm{c}(1) \neq \mathrm{c}(2) \neq c(3) \neq c(4) \neq c(5) \neq 0$ is easily rejected at the 5\% confidence level for all ASEAN-4 nations. The computed F-statistic for Malaysia at 14.30421 is greater than the upper critical bound of 4.68 for the $1 \%$ significance level, and hence the null hypothesis of no cointegration is rejected at that level. Similarly, Thailand's computed F-statistic of 3.930668 is greater than the upper critical bound of 3.79 and the null hypothesis is rejected at the $5 \%$ upper bound critical value. The computed F-statistic for Indonesia at 6.122780 and the Philippines at 4.693430 are all rejected at the $1 \%$ upper bound critical value.

Based on the test results, it is concluded that there exists a steady-state long-run relationship amongst Domestic Investment, FDI, Exports, Human Capital, and GDP Per Capita for Malaysia, Thailand, Indonesia, and the Philippines. In other words, for Malaysia, Thailand, Indonesia, and the Philippines, these variables do not move "too far away" from each other in the long-run.

The computed results of the long-run elasticities of the determinants of GDP Per Capita are shown in Table 3.

The estimated results show that for Malaysia, Domestic Investment, FDI, Exports, and Human Capital significantly and positively influence the level of GDP Per Capita. Human Capital is said to have a positive relationship with GDP Per Capita because the "illiteracy rate" used in the study has the correct negative sign which corresponds to a positive sign had "literacy rate" been used instead in the estimation. This is true of the study's other three ASEAN nations. The estimated coefficients imply that a $1 \%$ increase in Domestic Investment, FDI, and Exports will lead to a rise in GDP Per Capita by $0.1647 \%, 0.2122 \%$, and $0.3762 \%$ respectively. However, a $1 \%$ increase in the rate of illiteracy (Human Capital) will lead to a decrease of GDP Per Capita by $-0.5135 \%$. The significantly positive values for coefficients $\beta_{1}, \beta_{2}, \beta_{3}$ conform to both neo-liberal and dependency theories. The negative value of the rate of adult illiteracy (Human Capital) also conforms to neo-liberal and not contested by dependency theorists. However, the neo-liberal and dependency theorists differ on their postulation of the size of $\beta_{1}$ and $\beta_{2}$. A more robust coefficient for FDI as opposed to Domestic Investment means that $\beta_{2}$ contributes more to growth than $\beta_{1}$.

Hence, FDI flows are better than Domestic Investment flows in promoting growth in Malaysia which invalidates the postulation of FDI flows are not as good as Domestic Investment flows in promoting growth as hypothesized by the dependency side. As previously mentioned, this postulation comes under the "level of investment" argument which is rhetorical in dependency theory literature. This finding is supported by Wong and Jomo (2005) who stressed the importance of FDI on the Malaysian economy.

For Thailand, the estimated results show that only Domestic Investment, Exports, and Human Capital are significant determinants of growth in the nation. As such, a $1 \%$ increase in Domestic Investment and Exports will lead to an increase in GDP Per Capita by $0.2648 \%$ and $0.2775 \%$ respectively. A $1 \%$ increase in adult illiteracy rate will lead to a fall of $-0.7360 \%$ in GDP Per Capita. FDI is not significant in determining growth in the model. The significantly positive value for coefficient $\beta_{1}$ and the insignificance of $\beta_{2}$ validates the hypothesis that FDI is not as good as Domestic Investment in promoting growth. Hence, this finding lends support to the dependency school of thought and challenges the viewpoint that capital is capital regardless of its origin as put forth time and again by the neoliberals (Chang, 2003).

Similar to Malaysia, Indonesia's estimated results show that all four determinants in the study significantly influence the level of growth. Subsequently, a 1\% increase in Domestic Investment, FDI, and Exports will lead to an increase by $0.397 \%, 0.9046 \%$, and $0.2126 \%$ respectively. Conversely, a $1 \%$ rise in the adult illiteracy rate (Human Capital) will reduce growth by $-0.7395 \%$. The larger coefficient of $\beta_{2}$ than that of $\beta_{1}$ lends further support to the neoliberal school. Indonesia's result shows that indeed FDI is better than Domestic Investment in promoting growth. This finding conforms to Sjoholm (2002) and Thee (2005).

In the case of the Philippines, only Domestic Investment and Human capital are significant in determining the level of growth in the nation. A $1 \%$ increase in Domestic Investment will lead to a $1 \%$ increase in growth but a $1 \%$ increase in the rate of adult illiteracy will deteriorate growth by $-0.2143 \%$. Unexpectedly, FDI and Exports are not significant in determining growth. Hence, given that $\beta_{1}$ is significant and $\beta_{2}$ is insignificant, then the postulation that FDI is not as good as Domestic Investment is strongly supported here. This finding naturally further challenges the postulation of the neo-liberal theorists and conforms to Chang (2003).

\section{Conclusion}

The study compares and contrasts the "goodness" of two types of investments namely domestic investment with FDI in determining growth for four ASEAN nations spanning from 1970 to 2001 using the ARDL approach. ARDL developed by Pesaran et.al (2001) is most suitable for small sample size studies such as this. Exports and the rate of illiteracy were included to help explain the level of GDP per capita in each nation. Essentially, this study tests the postulation of dependency theorists that FDI is not as good as Domestic Investment in promoting growth and conversely that of neo-liberalism theorists that capital is capital regardless of origin and that FDI brings about many growth enhancing benefits to host-countries. 
Several important conclusions may be deduced from the growth model's estimation results. First, Gross Domestic Investment is common to all growth models in helping to explain growth levels. Second, FDI is significant in explaining growth levels only as far as Malaysia and Indonesia are concerned. Injecting more FDI as opposed to Domestic Investment will do much more to generate growth since the postulation of the neo-liberals appears valid in Malaysia and Indonesia. Both are great showcases in advancing the neo-liberal argument in "harnessing" globalization to promote economic growth. Alternatively, any downturn in FDI would also mean decreases in growth levels for both nations. Hence, it is also important that domestic investment be promoted more aggressively for sustainability of economic growth (Ariff, 2007). Thailand would appear to do better in promoting growth by focusing on domestic investment. The same argument appears valid for the Philippines.

In tandem with the neo-liberals, dependency theorists do not dispute the contribution of FDI flows to growth but the insignificance of FDI towards promoting growth in Thailand and the Philippines does not fall neatly in either school of thought. Perhaps, dependency theorists ought to adopt a more critical stance on FDI inflows by reviewing its automatic association with positive growth given the emergence of a new body of empirical evidence which warrants a rethink of this postulation (Mercinger, 2003).

Thus, the alleged importance of FDI via TNCs in the ASEAN region and the larger East Asian regional development can be challenged with regards to Thailand and the Philippines.

Third, exports are robust in determining growth levels in all nations except for the Philippines. Rasiah (2004) finds exporting manufacturing to be significant to growth levels in Malaysia, Thailand and Indonesia. It is well-known that there has been a strong FDI participation in the leading export manufacturing branches of electric-electronics and textile-garment in Malaysia (Rasiah, 2004). However, exports appear not to be significant in elevating growth levels in the Philippines. Bello (2005) postulates that export-oriented growth that was pursued by Newly-Industrialized Countries (NIC) is no longer possible especially for the Philippines in an era of tremendous manufacturing overcapacity and the resulting protectionism in developed-country markets that this has spawned. Even if developed-country protectionism were not a problem, export-oriented manufacturing would not be an advantageous strategy given, the tremendous advantage that China has in labor costs (Bello, 2005). Similar to Bello, Ariff (2007) predicts that after the Asian Financial Crisis debacle, the next crisis is likely to witness a stronger ringgit and weaker external demand for both primary commodities and limit Malaysia's ability to export out of the crisis. Hence, he maintains that FDI and exports can never be substitutes for domestic private investment and consumption expenditure.

Not surprisingly, literacy is an important factor in determining growth levels in all four nations. Hence, having a high percentage of literate adults would do much to boost FDI levels and it reinforces the need to assure quality education at the primary level although some ASEAN-4 governments tend to pay more attention to the tertiary education as opposed to primary. As such an education policy to ensure that all primary school children are literate which includes numerical literacy would serve these nations well in the long run. The Philippines had achieved universal primary enrollment much earlier in the 1970s, than the other Southeast Asian nations. Unfortunately, there has been a marked decline in access and quality of education in the Philippines, and there exists wide regional differences. It is estimated that two thirds of primary school children do not complete primary education and rate of completion varies by region. The level of attainment of basic knowledge has also diminished. The school system is socially regressive since children from poor families have access only to public schools and suffer all the consequences regarding quality. Despite the fact that it is government funded public school, parents are still expected to contribute to one third of their child's education [World Bank (2000) in Pangestu (2000)]. Hence, all four nations should formulate educational policies aimed at raising educational attainment to enhance human capital as well as growth (Te Velde, 2002).

\section{Acknowledgement}

The author is most grateful to Zulkornain Yusop, Law Siong Hook, and Zaleha Mohd. Noor, lecturers at Universiti Putra Malaysia, for their guidance.

\section{References}

Amin, S. (1976). Unequal Development. New York: Monthly Press Review.

Ariff, M. (2007). Strong domestic sector crucial to resilience. The New Straits Times. $28^{\text {th }}$ July, 2007. p. 24.

Baliamoune-Lutz (2004, April). Does FDI contribute to economic growth? Business Economics, p. 49-56.

Bello, W. (2005). The Anti-development state: The political economy of permanent crisis in the Philippines. London: Zed Books.

Bornschier, V. (1980). Multinational corporations and economic growth: A cross-national test of decapitalization thesis. Journal of Development Economics, 7. p. 191-210.

Bornschier, V. \& Chase-Dunn, C. (1985). Transnational corporations and under-development. New York: Prager Publishers. 
Bornschier, V., Chase-Dunn, C. \& Rubinson, R. (1978). Cross-national evidence of the effects of foreign investment and aid on economic growth and inequality: A survey of findings and a reanalysis. American Journal of Sociology, 84 (3), p. 651-682.

Borenzstein et. al.(1998). How does foreign direct investment affect economic growth? Journal of International Economics. 45. p. 115-135.

Chang, H-J. (2003). Globalisation, economic development, and the role of the state. Penang, Malaysia: Third World Network.

Chase-Dunn, C. (1975, December). The effects of international economic dependence on development and inequality: A cross-national study. American Sociological Review, 40, p.720-738.

Choe, J. I. (2003). Do foreign direct investment and gross domestic investment promote economic growth? Review of Development Economics, 7(1), p. 44-57.

Crane, G. T., \& Amawi, A. (1991). The theoretical evolution of international political economy. New York: Oxford University Press.

Dixon, W. J. and Boswell T. (1996, September). Dependency, disarticulation, and denominator effects: Another look at foreign capital penetration. American Journal of Sociology, 2 (102), p. 543-562.

Firebaugh, G. (1992, July). Growth Effects of Foreign and Domestic Investment. The American Journal of Sociology, 98 (1), p.105-1300.

Ghosh, B. N., (2001). Dependency theory revisited. Hampshire: England: Ashgate Publishing Limited.

Hsiao, C. \& Shen, Y. (2003). Foreign direct investment and Economic growth: The importance of institutions and urbanization. Economic Development \& Cultural Change. 51(4), p.883-896. The University of Chicago.

Kohpaiboon, A. (2003, December). Foreign trade regimes and the FDI-growth nexus: A case study of Thailand. The Journal of Development Studies, 40 (2), p. 55-69.

Jafee, D. (1986). Foreign investment and trade dependence. The Sociological Quarterly, 27(4), p.533-546.

Jansen, K. (1995). The macroeconomic effects of direct foreign investment: The Case of Thailand. World Development, 23(2), p.193-210.

Li, X., \& Liu, X. (2004). Foreign direct investment and economic growth: An increasingly endogenous relationship. World Development, 33 (3), p. 393-407.

Mercinger, J. (2003). Does foreign investment always enhance economic growth? Kyklos, (56), p. 491-508.

OECD (2004). Investment incentives and FDI in selected Asean countries. International Investment Perspectives. [Online] Available: http: //caliban.sourceoecd.org/vl=7407875/cl=26/nw=1/rpsv/ 6675/v2004n22/s5/p79.(Retrieved from July, 11, 2004)

Rasiah, R. (2004). Explaining growth, poverty, and distribution in Indonesia, Malaysia and Thailand. In A. R. Embong (Ed.), Globalisation Culture \& Inequalities (p.145-166). Bangi, Malaysia: Penerbit UNIVERSITI KEBANGSAAN MALAYSIA.

Stoneman, C. (1975, January). Foreign capital and economic growth. World Development, 3(1), p. 11-23.

Sjoholm, F. (2002). The challenge of combining FDI and regional development in Indonesia. Journal of Contemporary Asia. 31(3). p.381-393.

Sun, H. (1998, July). Macroeconomic impact of direct foreign investment in China: 1979-96. World Economy, 21(5), p. 675-694.

Te Velde, D.W. (2002). Government policies for inward foreign direct investment in developing countries: Implications for human capital formation and income inequality. Paris, France: OECD Development Centre. (Technical Paper No. 193). [Online] Available: http://www.oecd.org/dataoecd/8/23/1949219.pdf. (Retrieved from December 1, 1999)

Thee, K. W. (2005). The major channels of international technology transfer to Indonesia: An assessment. Journal of the Asia Pacific Economy, 10(2), p. 214-236.

United Nations Conference on Trade and Development(UNCTAD).Foreign Direct Investment Statistics.[Online].Available:http://stats.unctad.org/fdi/eng/TableViewer/wdsdim/dimensionp.asp\#.(Retrieved from September 9, 2005).

Usmani, T. \& Abdul Rashid, Z. (2000). FDI and economic development of Southeast Asia. Paper presented at the FEP seminar 2000 organised by Department of Accounting and Finance, Faculty of Economics and Management, Universiti Putra Malaysia. 
Pangestu, M. (2000). Poverty and income inequality in developing countries. A policy dialogue on the effects of globalization. Paris: OECD Development Centre.

Pesaran, M. H., Shin, Y. \& Smith, R. J. (2001). Bounds testing approaches to the analysis of level relationships. Journal of Applied Econometrics, 16, p. 289-326.

World Bank. (2003). World development indicators 2003. CD-ROM.

Wong, H. K., and Jomo, K.S. (2005, February). Before the storm: The impact of foreign capital flows on the Malaysian economy, 1966-1996. Journal of the Asia Pacific Economy, 10(1).p . 56-69.

Table 1. ASEAN-4 FDI (Million) Dollars and Growth (GDP Per Capita)

\begin{tabular}{|c|c|c|c|c|c|c|c|c|c|c|c|c|}
\hline \multirow{2}{*}{$\begin{array}{c}\text { GDP Per Capita/ } \\
\text { FDI }\end{array}$} & \multicolumn{12}{|c|}{ Year } \\
\hline & 70 & 75 & 80 & 85 & 90 & 95 & 96 & 97 & 98 & 99 & 2000 & $\begin{array}{c}200 \\
1\end{array}$ \\
\hline Malaysia FDI & 94 & $\begin{array}{c}350 . \\
49\end{array}$ & $\begin{array}{c}933 . \\
9\end{array}$ & $\begin{array}{c}694 . \\
71\end{array}$ & 2611 & 5815 & 7297 & 6323 & 2713 & 3895 & 3787 & 553 \\
\hline $\begin{array}{c}\text { Malaysia GDP Per } \\
\text { Capita }\end{array}$ & 394.05 & $\begin{array}{c}806 . \\
85\end{array}$ & $\begin{array}{c}1811 \\
.9\end{array}$ & $\begin{array}{c}2026 \\
.7\end{array}$ & $\begin{array}{c}2418 \\
.7\end{array}$ & $\begin{array}{c}4310 \\
.2\end{array}$ & $\begin{array}{c}4773 \\
.1\end{array}$ & $\begin{array}{c}4623 \\
.1\end{array}$ & $\begin{array}{c}3254 \\
.1\end{array}$ & $\begin{array}{c}3485 \\
.2\end{array}$ & $\begin{array}{c}3869 \\
.4\end{array}$ & $\begin{array}{c}369 \\
9\end{array}$ \\
\hline Thailand FDI & 42.8 & $\begin{array}{c}85.6 \\
2\end{array}$ & $\begin{array}{c}189 . \\
4\end{array}$ & $\begin{array}{c}163 . \\
55\end{array}$ & 2575 & 2070 & $\begin{array}{c}2337 \\
.7\end{array}$ & $\begin{array}{c}3881 \\
.8\end{array}$ & $\begin{array}{c}7491 \\
.2\end{array}$ & $\begin{array}{c}6090 \\
.8\end{array}$ & $\begin{array}{c}3350 \\
.3\end{array}$ & $\begin{array}{c}381 \\
3\end{array}$ \\
\hline $\begin{array}{c}\text { Thailand GDP } \\
\text { Per Capita }\end{array}$ & 198.2 & $\begin{array}{c}359 . \\
84\end{array}$ & $\begin{array}{c}692 . \\
54\end{array}$ & $\begin{array}{c}760 . \\
58\end{array}$ & $\begin{array}{c}1535 \\
.1\end{array}$ & $\begin{array}{c}2864 \\
.6\end{array}$ & $\begin{array}{c}3080 \\
.7\end{array}$ & $\begin{array}{c}2364 \\
.4\end{array}$ & $\begin{array}{c}1937 \\
.5\end{array}$ & $\begin{array}{c}2028 \\
.5\end{array}$ & $\begin{array}{c}1987 \\
.2\end{array}$ & $\begin{array}{c}187 \\
4\end{array}$ \\
\hline Indonesia FDI & 83 & 476 & 180 & 310 & 1092 & 4346 & 6194 & 4678 & -356 & $\begin{array}{c}-274 \\
5\end{array}$ & $\begin{array}{c}-455 \\
0\end{array}$ & $\begin{array}{c}-32 \\
79\end{array}$ \\
\hline $\begin{array}{c}\text { Indonesia GDP } \\
\text { Per Capita }\end{array}$ & 82.16 & $\begin{array}{c}242 . \\
46\end{array}$ & $\begin{array}{c}526 . \\
04\end{array}$ & $\begin{array}{c}543 . \\
49\end{array}$ & $\begin{array}{c}642 . \\
01\end{array}$ & $\begin{array}{c}1048 \\
.7\end{array}$ & $\begin{array}{c}1163 \\
.3\end{array}$ & $\begin{array}{c}1088 \\
.7\end{array}$ & $\begin{array}{c}475 . \\
17\end{array}$ & $\begin{array}{c}687 . \\
74\end{array}$ & $\begin{array}{c}738 . \\
01\end{array}$ & $\begin{array}{c}695 . \\
3\end{array}$ \\
\hline Philippines FDI & -1.04 & 114 & -106 & 12 & 550 & 1577 & 1618 & 1261 & 1718 & 1725 & 1345 & 982 \\
\hline $\begin{array}{c}\text { Philippines GDP } \\
\text { Per Capita }\end{array}$ & 183.2 & $\begin{array}{c}356 . \\
8\end{array}$ & $\begin{array}{c}676 . \\
59\end{array}$ & $\begin{array}{c}566 . \\
95\end{array}$ & $\begin{array}{c}726 . \\
26\end{array}$ & $\begin{array}{c}1084 \\
.6\end{array}$ & $\begin{array}{c}1185 \\
.1\end{array}$ & $\begin{array}{c}1151 \\
.3\end{array}$ & $\begin{array}{c}890 . \\
6\end{array}$ & $\begin{array}{c}1017 \\
.1\end{array}$ & $\begin{array}{c}975 . \\
29\end{array}$ & $\begin{array}{c}912 . \\
2\end{array}$ \\
\hline
\end{tabular}

Source: World Bank World Development Indicators (2003) and United Nations Conference on Trade and Development (UNCTAD) Foreign Direct Investment Online Statistics. 
Table 2. Bounds Test for Cointegration Test

\begin{tabular}{|c|c|c|c|}
\hline \multicolumn{4}{|c|}{ Null Hypothesis: No Cointegration } \\
\hline \multicolumn{4}{|c|}{ Computed F-statistic (Wald Test): } \\
\hline & Malaysia & 14.3 & \\
\hline & Thailand & 3.930 & \\
\hline & Indonesia & 6.122 & \\
\hline & Philippines & 4.693 & \\
\hline \multicolumn{4}{|c|}{ Critical Value } \\
\hline \multicolumn{4}{|c|}{ Lower } \\
\hline $1 \%$ & significance level & 3.41 & 4.68 \\
\hline $5 \%$ & significance level & 2.62 & 3.79 \\
\hline $10 \%$ & significance level & 2.26 & 3.35 \\
\hline \multicolumn{4}{|c|}{ Decision: Reject or Accept null hypothesis at $5 \%$ significance level } \\
\hline \multicolumn{4}{|c|}{ Note: The critical value is taken from Pesaran et. al. (2001). } \\
\hline \multicolumn{4}{|c|}{ Table C (iii) Case III. Unrestricted intercept and no trend } \\
\hline
\end{tabular}

The above table demonstrates that there exists a long-run relationship between growth and each of its determinants in the ASEAN-4 nations for the period surveyed.

Table 3. Long-run Elasticities

\begin{tabular}{|c|c|c|c|c|}
\hline & Malaysia & Thailand & Indonesia & Philippines \\
\hline Gross Domestic Investment & $0.1647^{* *}$ & $0.2648^{* * *}$ & $0.397^{* *}$ & $0.3131^{* *}$ \\
\hline FDI & $0.2122^{*}$ & 0.0927 & $0.9046^{*}$ & 0.0112 \\
\hline Exports & $0.3762^{*}$ & $0.2775^{* *}$ & $0.2126^{*}$ & 0.0137 \\
\hline Human Capital & $-0.5135^{*}$ & $-0.7360^{* *}$ & $-0.7395^{* *}$ & $-0.2143^{* * *}$ \\
\hline
\end{tabular}

Note: $* \quad * * \quad * * *$ denote significant at the $1 \%, 5 \%$, and $10 \%$ significance levels respectively

The above table illustrates the results of the cointegration test for growth and its determinants. The long-run elasticity of each of the explanatory variable is calculated by dividing the long-run coefficient of an explanatory variable with the long-run coefficient of the dependent variable which in this case is the Growth variable and multiplying it with the negative term. Normally the long-run coefficients are larger than the short-run coefficients. However, in this study there are instances when the reverse is true and this is the result of the lag lengths chosen for the short-run period. 
Table 4. Results of the Augmented Dickey Fuller and Phillips-Perron Unit Root Tests

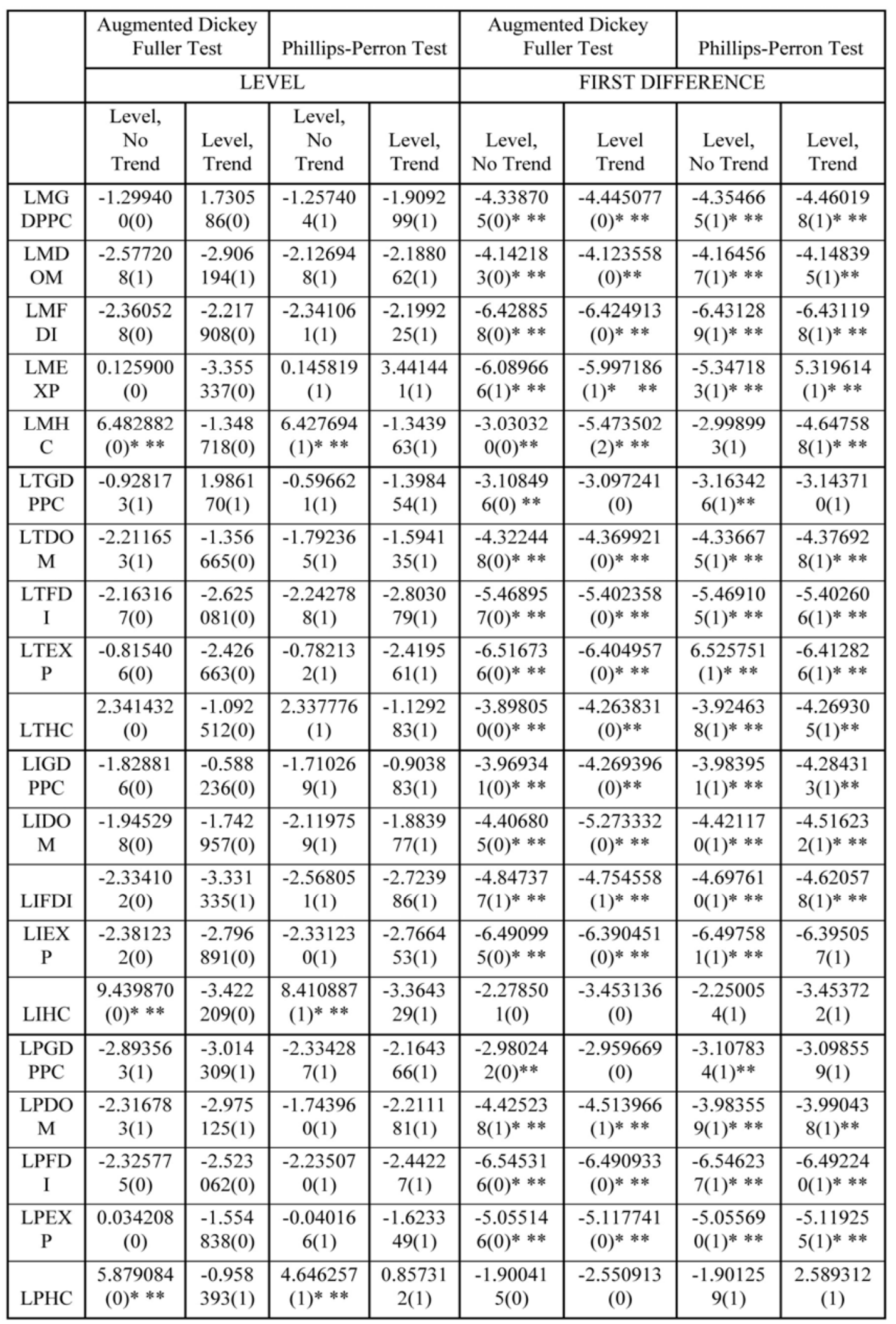

The above table shows $* / * *$ as denoting significant at the $1 \%$ and $5 \%$ levels, respectively. 
Table 5. Malaysia: Unrestricted Error Correction Model Results

\begin{tabular}{|c|c|c|c|}
\hline Variable & Coefficient & Std. Error & Prob. \\
\hline LMGDPPC(-1) & -1.164638 & 0.212942 & 0.0004 \\
\hline LMDOM(-1) & 0.191869 & 0.076274 & 0.033 \\
\hline LMFDI1(-1) & 0.247139 & 0.048805 & 0.0007 \\
\hline $\operatorname{LMEXP}(-1)$ & 0.438132 & 0.09894 & 0.0017 \\
\hline LMHC(-1) & -0.598083 & 0.130225 & 0.0013 \\
\hline DUM & 0.040629 & 0.011082 & 0.0052 \\
\hline D(LMGDPPC(-2)) & -1.229651 & 0.193078 & 0.0001 \\
\hline D(LMGDPPC(-3)) & -0.885732 & 0.238323 & 0.0048 \\
\hline $\mathrm{D}(\mathrm{LMDOM}(-2))$ & 0.379453 & 0.062907 & 0.0002 \\
\hline D(LMDOM(-3)) & 0.196242 & 0.092702 & 0.0634 \\
\hline D(LMDOM(-5)) & 0.174911 & 0.057565 & 0.0141 \\
\hline D(LMFDI1(-2)) & -0.203602 & 0.042074 & 0.0009 \\
\hline D(LMFDI1(-3)) & -0.289388 & 0.069905 & 0.0025 \\
\hline D(LMEXP(-2)) & -0.117637 & 0.090471 & 0.2258 \\
\hline $\mathrm{D}(\mathrm{LMHC}(-3))$ & 10.64281 & 2.228796 & 0.001 \\
\hline $\mathrm{D}(\mathrm{LMHC}(-4))$ & -2.773476 & 2.122969 & 0.2238 \\
\hline $\mathrm{C}$ & 3.725591 & 0.705339 & 0.0005 \\
\hline \multicolumn{4}{|l|}{$\mathrm{N}=26$} \\
\hline Adjusted R-squared & 0.858519 & & \\
\hline S.E. of regression & 0.006674 & & \\
\hline F-statistic & 10.48138 & & \\
\hline \multirow[t]{2}{*}{ Prob(F-statistic) } & 0.000586 & & \\
\hline & Test-Statistics & P-value & \\
\hline Jarque-Bera Normality Test & 1.433079 & 0.488440 & \\
\hline Breusch-Godfrey LM Test (Lag 1) & 0.931619 & 0.362709 & \\
\hline ARCH Test $\quad$ (Lag 2) & 0.827466 & 0.450914 & \\
\hline \multicolumn{4}{|l|}{ Ramsey Reset (Lag 3) } \\
\hline & 3.807807 & 0.076860 & \\
\hline
\end{tabular}

Malaysia's long-run results in as presented in Table 5 show that all the variables are significant at the 5\% level with the correct sign either in the neo-liberal or in the dependency school of thought. The F-statistic, which tests the overall significance of variables, justifies the inclusion of all variables in the growth model. The R-squared as well as Adjusted R-squared values suggest that at least over $80 \%$ of the variations in growth the level is explained by the variables included in the model. Hence, the overall fit of the model is good. The model also passed all diagnostic tests specified in the same table which renders the long-term estimates of this model to be reliable. The significance of the long-run dummy variable suggests that the economic downturn years have had an impact on Malaysia's economic performance. 
Table 6. Thailand: Unrestricted Error Correction Model Results

\begin{tabular}{|c|c|c|c|}
\hline Variable & Coefficient & Std. Error & Prob. \\
\hline LTGDPPC(-1) & -0.455249 & 0.135458 & 0.0047 \\
\hline $\operatorname{LTDOM}(-1)$ & 0.12054 & 0.066633 & 0.092 \\
\hline LTFDI(-1) & 0.042181 & 0.032372 & 0.2136 \\
\hline LTEXP(-1) & 0.126341 & 0.054602 & 0.0364 \\
\hline LTHC(-1) & -0.335062 & 0.10472 & 0.0064 \\
\hline DUM & -0.038464 & 0.007069 & 0.0001 \\
\hline D(LTGDPPC(-1)) & 0.951298 & 0.163922 & 0 \\
\hline D(LTGDPPC(-2)) & 0.524008 & 0.194949 & 0.0177 \\
\hline D(LTDOM(-1)) & -0.233316 & 0.051841 & 0.0005 \\
\hline $\mathrm{D}(\mathrm{LTDOM}(-2))$ & -0.170208 & 0.063283 & 0.0176 \\
\hline $\mathrm{D}(\mathrm{LTFDI}(-3))$ & -0.162265 & 0.043621 & 0.0023 \\
\hline $\mathrm{D}(\operatorname{LTEXP}(-1))$ & -0.099059 & 0.03906 & 0.0238 \\
\hline $\mathrm{D}(\mathrm{LTHC}(-2))$ & -2.655727 & 0.982109 & 0.0171 \\
\hline $\mathrm{C}$ & 1.329213 & 0.403326 & 0.0053 \\
\hline \multicolumn{4}{|l|}{$\mathrm{N}=28$} \\
\hline Adjusted R-squared & 0.870809 & & \\
\hline S.E. of regression & 0.006714 & & \\
\hline F-statistic & 14.99944 & & \\
\hline \multirow[t]{2}{*}{$\operatorname{Prob}($ F-statistic $)$} & 0.000005 & & \\
\hline & Test-Statistics & P-value & \\
\hline \multicolumn{4}{|l|}{ Jarque-Bera Normality Test } \\
\hline \multicolumn{4}{|c|}{ Breusch-Godfrey LM Test (Lag 1) } \\
\hline \multirow{4}{*}{$\begin{array}{l}\text { ARCH Test } \quad(\operatorname{Lag} 2) \\
\text { Ramsey Reset (Lag 3) }\end{array}$} & 3.231689 & 0.132150 & \\
\hline & 1.785894 & 0.190122 & \\
\hline & & & \\
\hline & 2.121840 & 0.155449 & \\
\hline
\end{tabular}

Thailand's long-run estimated results as in Table 6 show that exports and the rate of illiteracy are significant at the 5\% level while Gross Domestic Investment is significant at the $10 \%$ level of significance. FDI however is not significant. The results have the correct signs in either the neo-liberal or the dependency school of thought. The F-statistic shows that the overall model is very significant. The long-run dummy variable is significant at the $10 \%$ level and hence, retained in the equation. The high R-squared and adjusted R-squared suggest that almost $80 \%$ of the variables in the equation explains growth in Thailand. This model also passed all the diagnostic tests specified in the same table. 
Table 7. Indonesia: Unrestricted Error Correction Model Results

\begin{tabular}{|c|c|c|c|}
\hline Variable & Coefficient & Std. Error & Prob. \\
\hline LIGDPPC(-1) & -0.703003 & 0.169255 & 0.0016 \\
\hline LIDOM(-1) & 0.279082 & 0.108089 & 0.0255 \\
\hline LIFDI(-1) & 0.63596 & 0.139439 & 0.0008 \\
\hline LIEXP(-1) & 0.149477 & 0.048003 & 0.0099 \\
\hline LIHC(-1) & -0.519902 & 0.192495 & 0.0206 \\
\hline DUM & -0.11144 & 0.01039 & 0.0000 \\
\hline D(LIGDPPC(-2)) & -0.712119 & 0.179841 & 0.0022 \\
\hline D(LIDOM(-1)) & -0.170496 & 0.062428 & 0.0195 \\
\hline D(LIFDI $(-1))$ & -0.694436 & 0.199967 & 0.0052 \\
\hline D(LIFDI $(-2))$ & -0.466998 & 0.166791 & 0.0173 \\
\hline D(LIFDI $(-3))$ & -0.274596 & 0.117147 & 0.0389 \\
\hline D(LIFDI(-4)) & -0.067242 & 0.07567 & 0.3932 \\
\hline D(LIEXP(-1)) & -0.115146 & 0.0413 & 0.0176 \\
\hline $\mathrm{D}(\mathrm{LIHC}(-1))$ & -6.346714 & 2.554497 & 0.0303 \\
\hline $\mathrm{D}(\mathrm{LIHC}(-3))$ & -6.79508 & 3.20024 & 0.0572 \\
\hline $\mathrm{C}$ & 1.420297 & 0.643128 & 0.0494 \\
\hline \multicolumn{4}{|l|}{$\mathrm{N}=27$} \\
\hline Adjusted R-squared & 0.886394 & & \\
\hline S.E. of regression & 0.006424 & & \\
\hline F-statistic & 14.52403 & & \\
\hline Prob(F-statistic) & 0.000038 & & \\
\hline & Test-Statistics & P-value & \\
\hline \multicolumn{4}{|c|}{ Jarque-Bera Normality Test } \\
\hline & 4.916264 & 0.085595 & \\
\hline \multicolumn{4}{|c|}{ Breusch-Godfrey LM Test (Lag 1) } \\
\hline & 0.021163 & 0.887227 & \\
\hline \multicolumn{4}{|l|}{ ARCH Test $\quad(\operatorname{Lag} 2)$} \\
\hline & 0.002497 & 0.086958 & \\
\hline \multicolumn{4}{|l|}{ Ramsey Reset (Lag 3) } \\
\hline & 3.139270 & 0.997507 & \\
\hline
\end{tabular}

Indonesia's long-run estimated results indicate that all variables are significant at the 5\% level of significance as illustrated in Table 7. In fact, FDI and exports are significant at the $1 \%$ level of significance. The high significance of the long-run dummy variable strengthens its inclusion in the model. The variables have also the right signs that conform to either the neo-liberal or the dependency school of thought. The overall F-statistic shows that the entire model does well in explaining growth in Indonesia. The R-squared and the Adjusted R-squared indicate that almost $90 \%$ of the variables in the model explain growth in Indonesia. This model also passed all diagnostics tests. 
Table 8. The Philippines: Unrestricted Error Correction Model Results

\begin{tabular}{|c|c|c|c|}
\hline Variable & Coefficient & Std. Error & Prob. \\
\hline LPGDPPC(-1) & -0.76948 & 0.214259 & 0.0033 \\
\hline LPDOM(-1) & 0.240924 & 0.083499 & 0.0128 \\
\hline LPFDI(-1) & 0.008607 & 0.088901 & 0.9244 \\
\hline LPEXP(-1) & 0.010574 & 0.029526 & 0.726 \\
\hline LPHC(-1) & -0.164911 & 0.079038 & 0.0572 \\
\hline DUM & -0.022448 & 0.01051 & 0.0523 \\
\hline D(LPGDPPC(-1)) & 1.101337 & 0.216885 & 0.0002 \\
\hline D(LPGDPPC(-2)) & 0.346433 & 0.285751 & 0.2469 \\
\hline D(LPDOM(-1)) & -0.28196 & 0.070903 & 0.0016 \\
\hline D(LPDOM(-2)) & -0.134781 & 0.058421 & 0.0382 \\
\hline D(LPDOM(-3)) & -0.119225 & 0.04861 & 0.0291 \\
\hline $\mathrm{D}(\operatorname{LPEXP}(-1))$ & -0.129613 & 0.044879 & 0.0127 \\
\hline $\mathrm{D}(\operatorname{LPEXP}(-2))$ & 0.07764 & 0.046293 & 0.1174 \\
\hline $\mathrm{D}(\mathrm{LPHC}(-1))$ & 4.315091 & 2.307167 & 0.0841 \\
\hline $\mathrm{C}$ & 2.2232 & 0.692346 & 0.0068 \\
\hline \multicolumn{4}{|l|}{$\mathrm{N}=28$} \\
\hline Adjusted R-squared & 0.684732 & & \\
\hline S.E. of regression & 0.008744 & & \\
\hline F-statistic & 5.188667 & & \\
\hline Prob(F-statistic) & 0.002613 & & \\
\hline \multirow[b]{2}{*}{ Jarque-Bera Normality Test } & Test-Statistics & P-value & \\
\hline & 0.807287 & 0.667882 & \\
\hline Breusch-Godfrey LM Test (Lag 1) & 2.275835 & 0.157274 & \\
\hline \multirow[t]{2}{*}{ ARCH Test $\quad(\operatorname{Lag} 2)$} & & & \\
\hline & 0.648611 & 0.532070 & \\
\hline Ramsey Reset (Lag 4) & 3.496420 & 0.054976 & \\
\hline
\end{tabular}

The Philippines' long-run estimated results show that all variables except FDI and exports are significant at the $10 \%$ level as shown in Table 8 . However, Gross Domestic Investment is the most robust since it was significant at the $5 \%$. The 10\% significance level of the long-run dummy variable allows for its inclusion in the model. All variables have the correct signs and conform to either the neo-liberal or the dependency theories. The F-statistic's significance at the 5\% level is an indication that the entire model is good at explaining the level of growth in the Philippines. The R-squared and Adjusted R-squared suggest that at least $68 \%$ of the variables in the model explain the growth level in the Philippines. This model is deemed reliable since it passed all diagnostics tests. 


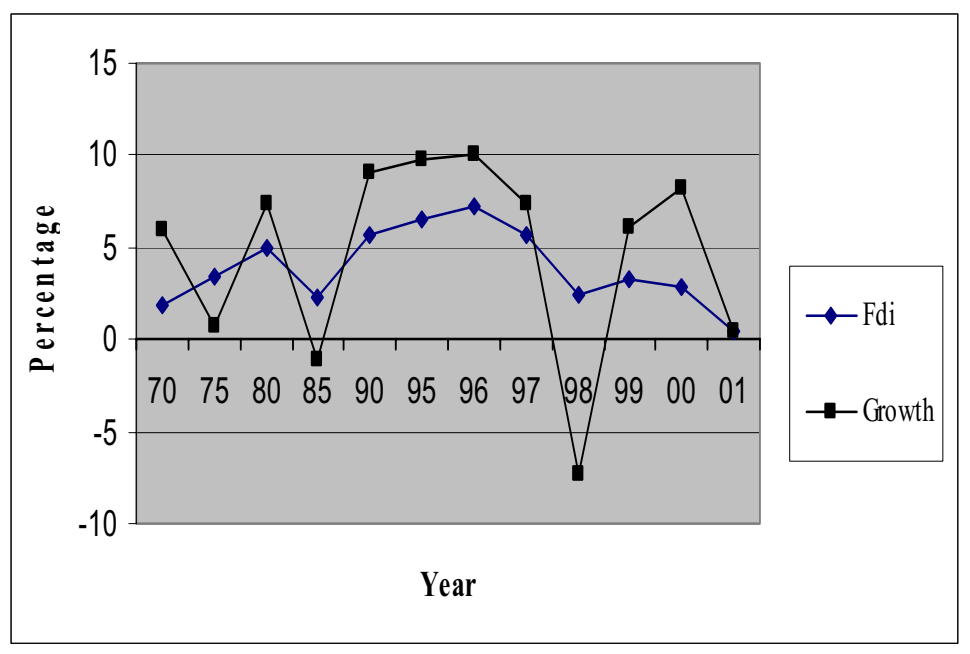

Figure 1a. Malaysia FDI and Growth

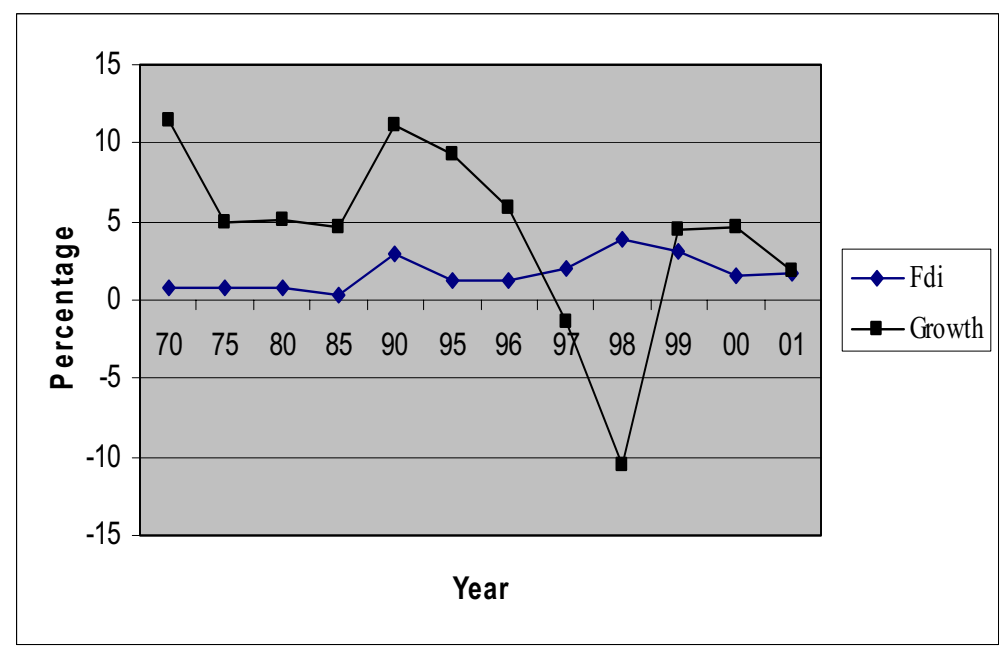

Figure 1b. Thailand FDI and Growth 


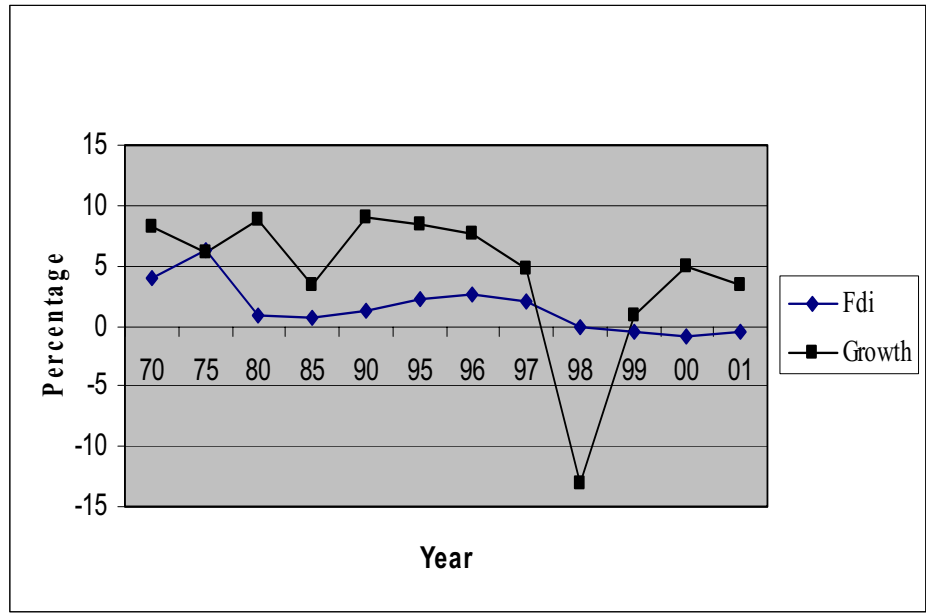

Figure 1c. Indonesia FDI and Growth

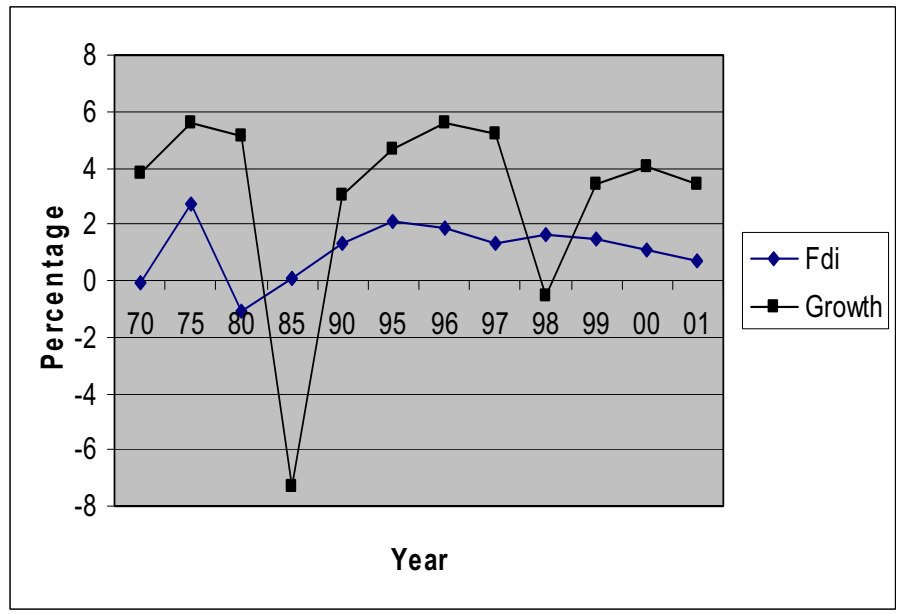

Figure 1d. Philippines FDI and Growth

The above illustrate FDI and Growth trends in the ASEAN-4 nations from 1970 through 2001. 


\begin{tabular}{|c|c|c|c|}
\hline Study & Model/Methodology & Dependent Variable & Findings \\
\hline $\begin{array}{l}\text { Bornschier } \\
\text { et. al. (1978). }\end{array}$ & 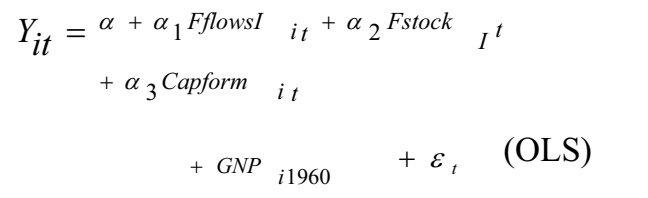 & $\begin{array}{l}\text { GNP per capita } \\
\text { growth rate }\end{array}$ & $\begin{array}{l}\text { FDI Flows } \quad+ \\
\text { FDI Stock } \quad-\end{array}$ \\
\hline Jansen (1995) & $\begin{array}{c}Y=C_{p r}+C_{g}+I_{p r}+I_{p u}+X-M \\
\text { (Cointegration Technique) }\end{array}$ & GDP growth rate & $\begin{array}{l}\text { FDI Flows }+ \\
\text { Export }+, \text { Import }+\end{array}$ \\
\hline $\begin{array}{l}\text { Dixon and } \\
\text { Boswell (1996) }\end{array}$ & $\begin{array}{l}Y=\alpha+\alpha_{1} F D I+\alpha_{2} D O M \\
+\alpha_{3} E N E R G Y+\alpha_{4} E X P+ \\
\alpha_{5} G N P P C \quad 65+\xi \\
(\mathrm{OLS})\end{array}$ & GNP growth rate & $\begin{array}{l}\text { FDI Flows }+ \\
\text { Domestic Flows }++\end{array}$ \\
\hline Sun (1998) & $\begin{array}{l}\ln G D P=\alpha_{0}+\alpha_{1} \ln D K+\alpha_{2} \ln D F I \\
+\alpha_{3} \ln F K+\alpha_{4} \ln L+v \\
\text { (Kmenta Model) }\end{array}$ & GDP & $\begin{array}{l}\text { FDI Flows }+ \\
\text { Domestic Flows }++\end{array}$ \\
\hline $\begin{array}{l}\text { Hsiao and } S \\
(2003)\end{array}$ & $\begin{array}{l}\log \left(G D P_{t}\right)=\mu_{11}+a_{11} \log \left(G D P_{t-1}\right)+ \\
a_{12} \log \left(F D I_{t}\right)+\varepsilon i_{1 t} \\
\text { (Three stage least squares) }\end{array}$ & GDP & FDI Flows + \\
\hline Mercinger (2003) & $\begin{array}{l}r G D P=a_{0}+a_{1} F D I-1+a_{2} F D I+a_{3} F D I+1 \\
+a_{4} G D P 0+a_{j} D U M_{j} \\
\text { (Cointegration Technique) }\end{array}$ & GDP growth rate & FDI Flows - \\
\hline $\begin{array}{l}\text { Baliamoune-Lutz } \\
\text { (2004) }\end{array}$ & $\begin{array}{l}Y_{t}=\alpha+\alpha_{1} F D I_{t}+\alpha_{2} \text { Exports }_{t}+\varepsilon_{t} \\
\text { (Cointegration Technique) }\end{array}$ & GDP growth rate & $\begin{array}{l}\text { FDI Flows }+ \\
\text { Exports }+\end{array}$ \\
\hline
\end{tabular}

Figure 2. Summary of Growth Models

The above summarizes the growth models of the literature surveyed in the study 